\title{
How global was the age of revolutions? The case of Mount Lebanon, $1821^{\dagger}$
}

\author{
Peter Hill \\ Department of Humanities, Northumbria University, Newcastle upon Tyne, NE1 8SB, UK \\ Corresponding author. E-mail: p.hill@northumbria.ac.uk
}

\begin{abstract}
This article addresses the question of the geographical scope of the 'age of revolutions' (c.1750-1850) through the case of a peasant uprising in Mount Lebanon in 1821. This uprising had similarities with recent and contemporary revolutions and rebellions, which have led some to suggest the influence of the ideas of the French Revolution of 1789 or the Greek Revolution of 1821. This article argues that influence at the level of ideas was unimportant, but that the similarities can plausibly be traced to similar and connected contexts at the level of political economy, as the expansion and crisis of military-fiscal states provoked opposition 'from below' and renegotiations of sovereignty. This focus on political economy rather than genealogies of ideas can then help define an 'age of revolutions' extending beyond Europe and the north Atlantic into the Ottoman empire, Latin America, and other regions.
\end{abstract}

Keywords: global history; Ottoman empire; popular politics; revolution

\section{Introduction}

Historians' ideas of the 'age of revolutions' of around 1750 to 1850 have themselves been revolutionized over the past several decades. The term was first popularized by two studies of the 1960s. Eric Hobsbawm's The Age of Revolution offered an account of a 'dual revolution', industrial and political, spreading outwards from England and France; R. R. Palmer's The Age of the Democratic Revolution portrayed an interaction between multiple revolutions in Europe and North America. ${ }^{1}$ Since the 1960s, and particularly perhaps in the last two decades, the 'age of revolutions' has become both more decidedly Atlantic and - perhaps more tentatively - global. From much recent work, a picture emerges of a transatlantic nexus, now expanded from Europe and North America to include Latin American independence struggles and the Caribbean, and re-weighted to give far more importance to imperial factors generally and to the slave trade and slave rebellions in particular. Rather than Hobsbawm's diffusionist spread from north-western European centres, or Palmer's interaction of distinct national revolutions, recent work on the Atlantic sees the 'age of revolutions' as an era of crisis within a set of transatlantic empires. Syntheses like those of Jeremy Adelman or Wim Klooster suggest resolutely transatlantic connections of both a 'material' kind (trade, wars, population movements) and a 'cultural' or ideational kind (circulation of revolutionary ideas and imperial examples), culminating in a mutually reinforcing set of

\footnotetext{
${ }^{\dagger}$ My thanks to Joanna Innes and Maurizio Isabella for their comments on drafts of this article; and to other participants in the Political Economy and Culture in Global History Reading Group at Oxford, and Jeremy Adelman at Princeton, for discussion of its themes.

${ }^{1}$ E. J. Hobsbawm, The Age of Revolution, 1789-1848 (New York: New American Library, 1964); R. R. Palmer, The Age of the Democratic Revolution: A Political History of Europe and America, 1760-1800 (Princeton: Princeton University Press, 1959). 
revolutionary events and imperial responses around the Atlantic and across Europe. ${ }^{2}$ Peter Linebaugh and Marcus Rediker, meanwhile, have suggested that the revolutionary response was the work of a similarly transnational actor, an Atlantic proletariat. ${ }^{3}$

A further extension of the concept beyond this Atlantic nexus, into a 'global' age of revolutions, has so far been less secure. Studies have multiplied which treat a wide variety of the world's regions 'in the age of revolutions' or 'a revolutionary age', and there has been an important collective volume on The Age of Revolutions in Global Context. ${ }^{4}$ But the kind of relationship these studies propose between the various localities and peoples and 'the age of revolutions' varies, and at times is left unclear. One major reason for this comparative uncertainty of the 'global' as compared to the 'Atlantic' wave of scholarship is undoubtedly the fact that the former generally concerns peoples operating in political cultures outside the European 'ecumene', shaped by Christianity and the Enlightenment, within which many (though hardly all) of the Atlantic instances can be situated. One kind of solution is that proposed by a recent collective volume, Facing Empire: Indigenous Experiences in a Revolutionary Age. While emphasizing the agency of indigenous peoples and their imbrication in 'the instabilities at the heart of the Age of Revolution', the editors accept that what brought these experiences together was the common challenge of facing an expanding European empire (in this case, the British). ${ }^{5}$ They make no strong claims for non- or anti-imperial connections between indigenous peoples, nor for their participation in 'revolutionary' enterprises which paralleled the political revolutions of the Euro-Atlantic nexus.

It is this kind of claim which is made, though at times ambiguously, in other recent studies of peoples outside the European-Christian ecumene, who went through major political upheavals in this same period between about 1750 and 1850. Some deal with movements which arose on the edges of the Atlantic nexus, but which have so far not been integrated into its historiography. Sinclair Thomson has argued that Tupac Amaru's insurrection in the Andes in the early 1780s should be seen as part of the Atlantic age of revolutions; and Paul Lovejoy has argued likewise for the series of jihads which overthrew and founded states in West Central Africa from the late eighteenth century to the mid nineteenth. ${ }^{6}$ In both cases, these writers suggest, the political movements they treat were not only innovative and transformative within their own societies, but also analogous to, and connected with, the 'classic' revolutions of the Atlantic nexus. They also insist, however, on these movements' distinctive local ideologies - Inca sovereignty in the Andes, holy war for pure religion in West Africa - which set them apart from the (purportedly) democratic, republican, or Enlightenment-inspired revolutions of the Atlantic nexus. ${ }^{7}$ While both authors outline convincingly some of the ways in which these ideologies flowed together, subsequently, with Enlightenment-inspired ones within the Atlantic nexus - the Andean rebellion as an inspiration to European radicals, the role of jihad-influenced West Africans in certain slave rebellions in the Caribbean ${ }^{8}$ - they stop short of suggesting a common set of causes for the 'simultaneity and radical features' shared by these movements and those of the Atlantic

\footnotetext{
${ }^{2}$ Jeremy Adelman, 'An Age of Imperial Revolutions', American Historical Review 113, no. 2 (2008): 319-40; Wim Klooster, Revolutions in the Atlantic World: A Contemporary History (New York: New York University Press, 2009), 1-10, 158-74.

${ }^{3}$ Peter Linebaugh and Marcus Rediker, The Many-Headed Hydra: The Hidden History of the Revolutionary Atlantic (London: Verso, 2002).

${ }^{4}$ David Armitage and Sanjay Subrahmanyam, eds., The Age of Revolutions in Global Context, c.1760-1840 (Basingstoke: Palgrave Macmillan, 2010).

${ }^{5}$ Kate Fullagar and Michael A. McDonnell, 'Introduction: Empire, Indigeneity, and Revolution', in Facing Empire: Indigenous Experiences in a Revolutionary Age, ed. Kate Fullagar and Michael A. McDonnell (Baltimore: John Hopkins University Press, 2018), 11.

${ }^{6}$ Sinclair Thomson, 'Sovereignty Disavowed: The Tupac Amaru Revolution in the Atlantic World', Atlantic Studies 13, no. 3 (2016): 407-31; Paul E. Lovejoy, Jihad in West Africa During the Age of Revolutions (Athens, OH: Ohio University Press, 2016).

${ }^{7}$ Lovejoy, Jihad in West Africa, 12, 21, 98; Thomson, 'Sovereignty Disavowed', 411, 424-5.

${ }^{8}$ Thomson, 'Sovereignty Disavowed', 418-20; Lovejoy, Jihad in West Africa, 27-8.
} 
nexus. ${ }^{9}$ Their accounts of the movements' motivations and antecedents emphasize, instead, their autonomous Andean and West African development. ${ }^{10}$

Two more recent studies go a little further. Toby Green argues that the West African jihads and rebellions studied by Lovejoy should be seen as the result of a clash between 'aristocratic and democratic forces' in a context of 'rising inequality', and hence as forming part of the 'Age of Revolution'. ${ }^{11}$ While making a strong case for West Africa's integration into Atlantic politicoeconomic dynamics, Green does not pursue further the comparison of revolutionary episodes. Ali Yaycioglu's study of political convulsions of the central provinces of the Ottoman empire between 1760 and 1808, meanwhile, draws on hints from Christopher Bayly to suggest a possible comparative taxonomy. ${ }^{12}$ Yaycioglu sees these Ottoman upheavals within a framework of alternative responses to political crisis. One possible response was 'top-down', based on a centralizing state; another was 'bottom-up', based on communities claiming to govern themselves; a third was 'negotiated', based on contractual partnership. ${ }^{13}$ The Ottoman crisis which these responses tried to resolve was, he suggests, part of a broader pattern shared with the Euro-Atlantic world of the age of revolutions. ${ }^{14}$ And he implies that the three types of response are also in some sense comparable to the political solutions attempted in the Euro-Atlantic world: rather like Green, he notes their similarity to the three broad concepts of 'classical political philosophy': monarchy, democracy, and aristocracy. ${ }^{15}$ Yet Yaycioglu does not attempt to outline specific causal connections between the development of 'crisis' in the Ottoman empire and that in the Atlantic world; nor does he pursue the intriguing suggestion of parallelism between Ottoman political responses and those of the Euro-Atlantic revolutionary world.

This leaves us with something of a difficulty. If movements like those of the Andes, West Africa, and the central Ottoman provinces, arose out of local dynamics and logics of change quite independent of the classic 'age of revolutions', perhaps we should resist the extension of the concept of the 'age of revolutions' beyond the Atlantic nexus. Their simultaneity might then be regarded as a matter of chance, or an effect of historiographical Eurocentrism, as historians attempt to force every political upheaval that happened between 1750 and 1850 into a common framework derived from the Euro-Atlantic zone: we should instead seek alternative regional chronologies of historical change. ${ }^{16}$ Yet there remains the problem not only of these movements' simultaneity but also of their apparent parallelism: the fact that they have seemed, to some contemporaries and some later scholars, to be attempting to do similar 'revolutionary' things. In an effort to explain this, we might attempt to challenge the idea that these movements belonged to separate, local political cultures, and accord a larger significance than Thomson, Lovejoy, or Yaycioglu do to the ideological links between West Africa and the Caribbean, or the Andes, the Ottoman empire, and Europe.

In an attempt to move the discussion forward, I present here a case study drawn from another region often seen as peripheral to the Euro-Atlantic world: the small Ottoman sub-province of Mount Lebanon in the south-east Mediterranean. In 1821, this province saw the emergence of

\footnotetext{
${ }^{9}$ Thomson, 'Sovereignty Disavowed', 412.

${ }^{10}$ Ibid., 408; Lovejoy, Jihad in West Africa, ch. 2, 98.

${ }^{11}$ Toby Green, A Fistful of Shells: West Africa from the Rise of the Slave Trade to the Age of Revolution (London: Allen Lane, 2019), 401, 428.

${ }^{12}$ Ali Yaycioglu, Partners of the Empire: The Crisis of the Ottoman Order in the Age of Revolutions (Stanford: Stanford University Press, 2016); C. A. Bayly, The Birth of the Modern World, 1780-1914: Global Connections and Comparisons (Oxford: Blackwell, 2004), 23-120. Aysel Yıldız, Crisis and Rebellion in the Ottoman Empire: The Downfall of a Sultan in the Age of Revolution (London and New York: I.B. Tauris, 2017), also argues for the inclusion of these Ottoman developments in an 'age of revolutions' framework.

${ }^{13}$ Yaycioglu, Partners of the Empire, 14-15, 240.

${ }^{14}$ Ibid., 4-9, 241.

${ }^{15}$ Ibid., 15.

${ }^{16}$ As suggested in two chapters of Armitage and Subrahmanyam, Age of Revolutions in Global Context: Joseph C. Miller, 'The Dynamics of History in Africa and the Atlantic "Age of Revolutions"', 101-24; Kenneth Pomeranz, 'Their Own Path to Crisis? Social Change, State-Building and the Limits of Qing Expansion, c. 1770-1840', 189-208.
} 
two substantial leagues among peasant commoners who refused to pay increased taxes imposed by their rulers. They made several political innovations: the idea of a commoner collectivity, written pacts binding this collectivity together, and its use of delegates. The first league negotiated with the ruling elite with some success, leading to a constitution-like agreement binding both commoners and various sections of the elite; the second league was put down by force. This instance is instructive because it presents marked parallels with the 'classic' Euro-Atlantic revolutionary developments of a similar period, specifically in the self-organization of commoners for their own ends, and in the use of constitution-like pacts. This fact has led some historians to suggest that these Lebanese developments were influenced by the French revolutionary or liberal tradition. ${ }^{17}$ The leagues also occurred simultaneously with a far more serious rebellion against the Ottoman empire in the Danubian and then the Greek provinces, which ultimately led to the independence of a small Greek state; and these outbreaks followed on the heels of revolutionary risings in Spain, Portugal, and Naples in 1820. This, as well as their occurrence within the longer period of the 'age of revolutions', might lead us to seek some shared logics and causes.

Mount Lebanon in 1821 presents us with a useful test case for different conceptions of an age of revolutions beyond the confines of Europe and the Atlantic world. I enquire first into the possibility of ideological connections: can we attribute the leagues' political innovations to the inspiration of the French or Greek revolutions, or must we regard them as deriving from a more local political culture? I then ask about possible links on a more material level: can we see both Lebanese peasants and Euro-Atlantic revolutionaries as responding to a shared set of politico-economic pressures? Based on my answers to these questions, I present suggestions towards a possible framework for understanding the age of revolutions within and beyond the Euro-Atlantic world.

\section{Commoners assembled}

Early in 1821, Abdallah Pasha, the newly appointed Ottoman governor of Acre in Palestine, demanded an excessively high sum in taxes from the emir Bashīr Shihābī, who held the district of Mount Lebanon from him as a tax farm. After attempts at negotiation within a delicately balanced system of power-sharing among Mount Lebanon's own multi-religious elite, Emir Bashīr decided to demand the extra money mainly from the Christian peasants of the northern part of his domains. But in March, these Christian commoners gathered together, armed, at the village of Anțalyās, and swore to resist the tax demands. After negotiations failed, Bashīr resigned the emirate and went into temporary exile inland, along with his most powerful supporter among the Lebanese elite, the Druze leader Bashīr Jumblāt. He left the emirate to two rival members of the Shihābi family, emirs Hasan and Salmān, who were supported by a different faction of the multi-religious elite. The commoners made a pact with them not to raise the taxes, and they were invested as joint emirs. But Abdallah Pasha grew impatient when they were unable to fulfil their conflicting obligations to him and to the commoners; and he did not oppose Emir Bashir when he quietly returned to Mount Lebanon in June. Emir Bashïr now engineered a new pact, involving only moderate taxation, with much of the Mountain elite and some commoner leaders from the north-central districts, excluding those further north. He then turned to the districts further north to extract his taxes. Commoners here resisted in the second league of Lihfid in the autumn, and attempted to ally with other elite factions. But they were decisively crushed by the troops of Emir Bashīr's ally, Bashīr Jumblāț, and harsh punishments and fines imposed. ${ }^{18}$

\footnotetext{
${ }^{17}$ See below, nn. 24, 25, 122.

${ }^{18}$ Sources for these events, cited below, comprise: a few documents associated with the rising itself; contemporary reports by French consuls and a Catholic cleric; and chronicles written from the 1820s to the 1880s. The most detailed studies are Iliya Harik, Politics and Change in a Traditional Society: Lebanon, 1711-1845 (Princeton: Princeton University Press, 1968), and Axel Havemann, Rurale Bewegungen im Libanongebirge des 19. Jahrhunderts. Ein Beitrag zur Problematik sozialer Veränderungen (Berlin: K. Schwarz, 1983).
} 
The 1821 movements were not without precedent: chroniclers mention earlier anti-tax revolts in a central Lebanese district in 1800 and 1805, while lesser disputes with tax collectors were doubtless frequent. ${ }^{19}$ But the two leagues of the spring and autumn of 1821 were more serious, covering several districts of north-central Mount Lebanon and gathering several thousand armed men. ${ }^{20}$ They were also more organized, initiating novel forms of political organization and language. Peasants and other commoners gathered in a large, armed assembly and swore an oath of mutual support. They sent messages to other villages or districts urging them to join them and send delegates. They also appointed delegates to negotiate for them, and a man of rank as titular head; Maronite priests sometimes served as their scribes and may have originated some of their organizational forms. Their aim was not to take over political power, but to impose their wishes on the emir and the Ottoman state, by concluding alliances with other factions and binding the ruling emirs by pacts not to raise taxes. ${ }^{21}$ In this sense their role was similar to that of other factions within the pluralistic system of negotiations backed up by violence that constituted Mount Lebanon politics. But previous factions had invariably been organized around the small number of elite families of rank - this was a new kind of political actor, referring to itself in terms of the 'àmmiyya (commoners or commonalty) and jumhūr (crowd or populace), and to its own distinct șälih (good or interest).

These distinctive features were later taken up by subsequent popular movements among Lebanese Maronite Christians: an 1840 rebellion against the occupying troops of Mehmed Ali of Egypt, a sustained uprising against the lords of one district in 1858, and the violence of sectarian militias in $1860 .^{22}$ Hence 1821 can be seen as the beginning of a distinctive local tradition of popular politics, one which later took on the varied connotations of Lebanese nationalism, Maronite sectarianism, and popular rebellion against 'feudalism'. It is this later evolution that has led many subsequent historians to see the events of 1821, and still more so the later movements, as ideologically deriving from the European age of revolutions. Jumhür was, after all, the term used by Napoleon's Arabic translators to render the French 'republic' on his invasion of Egypt; ${ }^{23}$ and the related jumhüriyya became the usual Arabic term for republic. Later historians

\footnotetext{
${ }^{19}$ Ṭannūs ibn Yūsuf Shidyāq, Kitāb akhbār al-a yān fì Jabal Lubnān (Tales of the Notables in Mount Lebanon) (Beirut: al-Maktaba al-Sharqiyya, 1970), 375-6, 384-5; Amīr Ḥaydar Ạ̣mad al-Shihābī, Lubnān fì 'ahd al-umarā' al-Shihābīyīn: wa-huwa al-juz' al-thānī wa-al-thālith min Kitậb al-Ghurar al-hisān fì akhbār abnā' al-zamān (Lebanon in the Era of the Shihābi Emirs, Being the Second and Third Parts of 'The Finest Highlights of Contemporaries' Reports') (Beirut: alMațba 'a al-Kāthūlīkiyya, 1933), 1:203-5, 3:436-7; Amīr Ḥaydar Aḥmad al-Shihābī, Tārīkh Aḥmad Bāshā al-Jazzār (History of Ahmad Pāshā al-Jazzār) (Beirut: Maktabat Anțwān, 1955), 478-80. For a seventeenth-century attack on tax collectors, see Jirjis Zughayb, 'Awdat al-Nașārā ilā Jurūd Kisrawān (The Christians' Return to the Mountains of Kisrawān) (Beirut: Jarrūs Briss, 1983), 12; for a nineteenth-century one, see Rose to Catziflis, 7 June 1844, FO 226/38, The National Archives, London (hereafter cited as TNA). For elsewhere in the Ottoman empire, see Jane Hathaway, ed., Mutiny and Rebellion in the Ottoman Empire (Madison: University of Wisconsin, 2002).

${ }^{20}$ Estimates for the initial gathering at Anțalyās range from 6,000 to 30,000 men: Shidyāq, Akhbār al-a $y \bar{a} n$, 401; Martin (Journal no. 3), 23 March 1821, Seyde [Sidon], 306CCC/27, Archives du Ministère des Affaires Étrangères, Paris (hereafter cited as AE); Mattā Shahwān, 'Hayāt Mattā Shahwān' ('Life of Mattā Shahwān'), in Anțūniyūs al- 'Aynțūrīnī, Mukhtaṣar Tārīkh Jabal Lubnān (Brief History of Mount Lebanon) (Beirut: Dār Lahad Khāțir, 1983), 8; letter from Father Ighnātiyūs Sarkīs, 25 April 1821, Scritture riferite nei Congressi: Ospizio de Maroniti di Roma (hereafter cited as SC Ospizio) 2, 433r, Archives of the Sacra Congregatio de Propaganda Fide, Rome, discussed in Elias Kattar, 'Les insurrections paysannes au Mont-Liban au XIXe siècle d’après les archives de la Congrégation De Propaganda Fide', Mélanges de l'École française de Rome. Italie et Méditerranée 109, no. 2 (1997): 678-9.

${ }^{21}$ Martin (Journal no. 4), 1 April 1821, AE 306CCC/27; Shahwān, 'Hayāt Mattā Shahwān', 9.

${ }^{22}$ Asad Rustum, Bashīr bayna al-Sultān wa-l- 'Azìz, 1804-1841 (Bashīr Between the Sultan and the Khedive, 1804-1841) (Beirut: al-Jāmi'a al-Lubnāniyya, 1956), 2:173-80; Ussama Makdisi, The Culture of Sectarianism: Community, History, and Violence in Nineteenth-Century Ottoman Lebanon (Berkeley and Los Angeles: University of California Press, 2000), chap. 6.

${ }^{23}$ Peter Hill, '5 May 1815, Egyptian Anxieties', in The Last Stand: Napoleon's 100 Days in 100 Objects, ed. Katherine Astbury, Katherine Hambridge, and Mark Philp (Warwick Digital Humanities, 2015), http://www.100days.eu/items/show/81; Ami Ayalon, 'Semantics and the Modern History of Non-European Societies: Arab "Republics" as a Case Study', Historical Journal 28, no. 4 (1985): 821-34.
} 
would read Lebanese peasants' jumhūr, too, as a republic; the 'àmmiyya became a commune or parliament, and sālih the general interest or public welfare; their elite opponents represented 'feudalism'. ${ }^{24}$ Behind this lay the suggestion that the 1821 movement, like its successors, was inspired at least in part by ideas and institutions derived from the French republican tradition'. 25

Certainly some among the Mount Lebanon elite had knowledge - albeit imprecise - of the French Revolution and its innovative political forms. Emir Bashïr's court poet wrote an account of the French occupation of Egypt, using the term jumhür (among others) for the French 'republic' and for its 'national assembly'. ${ }^{26}$ Not long afterwards, a Syrian Christian merchant in Egypt sponsored Arabic translations of French and Greek Enlightenment writings, and at least one elite Christian at Emir Bashīr's court, Mīkhā'īl Mishāqa, was profoundly influenced by these. ${ }^{27}$ But he also remained staunchly loyal to Emir Bashīr during and after the 1821 uprisings, and was dismissive of popular involvement in politics. ${ }^{28}$ In both cases, however, wealthy merchants and court figures were at a considerable cultural distance from rebellious north Lebanese peasants.

The elite groups with the closest links to these commoners were their local village shaykhs, and the Maronite Catholic clergy who lived among them as parish priests and monks. Some clerics reportedly played an important role in the 1821 leagues: the Church and monasteries too were exposed to the emir's tax demands. ${ }^{29}$ Maronite clergy possessed networks extending to Livorno, Marseille, and, of course, Rome; priests reported to the Maronite Patriarch from around the Mediterranean on the progress of the revolutionary wars. 'What a vast overturning (inqiläb) in so short a time!' one wrote after French troops occupied Rome in 1798: the Church's order was destroyed and the people 'behave like beasts'. ${ }^{30}$ Yet, as this instance shows, their view of these revolutionary events, so far as it is recorded, was wholly negative: this was the force which had ruined the Catholic Church, seizing their own Maronite monastery in Rome. ${ }^{31}$ Close to this clerical point of view was a north Lebanese village shaykh with Church ties, who was executed for his part in the Liḥfid rising: Anțūniyūs al- 'Aynțūrīnī. In 1819 he included in his chronicle of Mount Lebanon a brief account of the French Revolution and Napoleon's wars - but this expresses

\footnotetext{
${ }^{24}$ Khalīl Hammām Fā'iz, Abū Samrā Ghānim aw al-baṭal al-Lubnānī (Abū Samrā Ghānim, or the Lebanese Hero) (Cairo, 1905), 53; M. Jouplain [Būlus Nujaym], La question du Liban. Étude d'histoire diplomatique \& de droit international (Paris: A. Rousseau, 1908); Harik, Politics and Change, 213-14, 220; Toufic Touma, Paysans et institutions féodales chez les druses et les maronites du Liban du XVIIe siècle à 1914 (Beirut: Université Libanaise, 1971), 1:123-32; Issam Khalifé, 'Les révoltes sociales au Mont-Liban (1820-1859)', in La Révolution française et l'Orient, 1789-1989 (Paris: Cariscript, 1989), 49-61; John Chalcraft, Popular Politics in the Making of the Modern Middle East (Cambridge: Cambridge University Press, 2016), 129.

${ }^{25}$ Joel Beinin, Workers and Peasants in the Modern Middle East (Cambridge: Cambridge University Press, 2001), 31. For further discussion of this historiography, see Peter Hill, 'Asad Rustum and the Events of 1840: Between Narratives of Modernity and Documentary Exactitude’, forthcoming in Philological Encounters 6 (2021).

${ }^{26}$ Niqūlā ibn Yūsuf al-Turk, Histoire de l'expédition des français en Égypte (Paris: Imprimerie Royale, 1839), title page, 5, 18.

${ }^{27}$ Peter Hill, 'The First Arabic Translations of Enlightenment Literature: The Damietta Circle of the 1800s and 1810s', Intellectual History Review 24, no. 2 (2015): 209-33.

${ }^{28}$ See his own account: Mīkhā'îl Mishāqa, Murder, Mayhem, Pillage, and Plunder: The History of the Lebanon in the 18th and 19th Centuries by Mikhayil Mishaqa (1800-1873), trans. Wheeler N. Thackston Jr (Albany: SUNY Press, 1988), 127-9.

${ }^{29}$ Shidyāq, Akhbār al-a 'yān, 401; İsā Iskandar Ma 'lūf, 'al-Azjāl fī al-Amīr Bashīr al-Shihābī al-Kabīr' ('Popular Poems on Emir Bashīr al-Shihābī the Great'), al-Manāra 8 (1937): 120; Manșūr Hattūnī, Nabdha tārīkhiyya fī al-muqāta 'a al-Kisrawāniyya: tantawī 'alā muqaddima wa-thalāthat aqsām (Historical Opuscule on the District of Kisrawān, Containing an Introduction and Three Parts) (Kaslik: Dār Mārūn 'Abbūd, 1987), 247; Shahwān, 'Hayāt Mattā Shahwān', 11.

${ }^{30}$ Nasser Gémayel, 'La Révolution française vue par des témoins maronites', in La Révolution française et l'Orient, 258. See also ibid., 259-70; and Buțus Fahd, Tārīkh al-rahbāniyya al-Lubnāniyya bi-far 'ay-hā al-Halabī wa-al-Lubnānī (History of the Lebanese Monastic Order, with its Aleppine and Lebanese Branches) (Jūniya: Maṭba at al-Karīm, 1963), 5:490-501.

${ }^{31}$ See Nasser Gémayel, Les Échanges culturels entre les Maronites et l'Europe. Du Collège maronite de Rome (1584) au Collège de 'Ayn-Warqa (1789) (Beirut: Impr. Y. et Ph. Gemayel, 1984), 1:85-8.
} 
only dismay at the 'great upset and confusion' of the times, the killing of Louis XVI, and the attacks on Church and clergy. ${ }^{32}$

It is possible that Maronite clergy or shaykhs like 'Aynțūrīnī had heard of the role played by Catholic clerics in popular movements - counter-revolutionary more often than revolutionary across the Mediterranean, and this might conceivably have influenced their willingness to participate in the commoner leagues. But it seems distinctly unlikely that they would have called on French revolutionary models in order to do so - not least because they had more local precedents to hand. 'Aynțūrinī's history relates with approval the 1759 rising of Christian commoners in his northern Lebanese district to drive out their Shia Muslim lords and replace them with Maronite village shaykhs, including his own father. They had gathered at the Maronite stronghold of Ehden and sworn on the Bible and the Sacrament (prepared by the bishop) 'not to betray, and to spend ... their necks' blood' in the cause. ${ }^{33}$

\section{One word, one blow, one honour}

In fact, if we put aside the later evolution of the Lebanese tradition of popular politics and the 'modern' connotations which terms like jumhūr acquired, we hardly need to turn to Europe to explain the innovations of 1821. Precedents for all of them can be found in the existing political culture of Mount Lebanon and Ottoman Syria, either among commoners at village level or among the elite. Oaths sworn in churches and written contracts were used to bind peasants and lords to sharecropping agreements; ${ }^{34}$ villagers made written agreements among themselves, or with outsiders, over shared resources such as water rights. ${ }^{35}$ Written pacts of a political kind were used to bind together members of the fissiparous Mountain elite, and to hold commoners to a particular elite faction. ${ }^{36}$ The language of such agreements, stressing unity, penalties for traitors, and sacred sanctions, is similar to that found in pacts of the 1821 commoner movement and its successor of 1840. The 1821 pact of Bsha la village runs, 'we will all be brothers: one soul, one interest (șālih), one word, one blow, and one honour'. ${ }^{37}$ The covenant sworn by the 1840 rebels in the church of Anțalyās, in evocation of the oath taken there in the spring of 1821, imposed religious and social sanctions for oath-breaking. 'If the least disturbance should come from us, we will be excluded from our religion and cut off from the community of the Druze', swore the Druze; the Christians pledged: 'he among us who betrays, St Elias will be his enemy, and his death will not be in the religion of Christ'. ${ }^{38}$ Meanwhile, delegates (wakils) representing their principals in monetary and administrative affairs were employed by merchants, churchmen, and the ruling emir himself. ${ }^{39}$ One chronicler suggested that the commoners of 1821 adopted the institution from the clergy,

\footnotetext{
32‘ Aynțūīnī, 'Mukhtașar Tārìkh Jabal Lubnān' ('Brief History of Mount Lebanon'), Bibliothèque Orientale MS 1699, 185, 190, Université de Saint-Joseph, Beirut. He even reproduces Louis XVI's heavily Catholic testament (191-6), as had Emir Bashïr's court poet Niqūlā al-Turk: see Histoire de l'expédition des français, 5-10 (the two translations are different, and presumably independent). 'Aynțūrīn̄’s sections on France are omitted from printed editions. On 'Aynțūrīnī, see Harik, Politics and Change, 136-9.

${ }^{33}$ 'Aynțūin̄in, Mukhtașar, 134. See also Stefan Winter, The Shiites of Lebanon under Ottoman Rule, 1516-1788 (Cambridge: Cambridge University Press, 2010), 168-71.

${ }^{34}$ Dominique Chevallier, La Société du Mont Liban à l'époque de la révolution industrielle en Europe (Paris: Paul Geuthner, 1971), 131, 136-45; see also Touma, Paysans et institutions féodales, 2:811.

${ }^{35}$ William Polk translates three examples from a mainly Druze village: The Opening of South Lebanon, 1788-1840: A Study of the Impact of the West on the Middle East (Cambridge, MA: Harvard University Press, 1963), 60-1, 64-5, 67-8.

${ }^{36}$ See Chevallier, La Société du mont Liban, plate XVII and 132-6; Touma, Paysans et institutions féodales, 2:424-5, 431, 812; Yūsuf Ibrāhīm Yazbik, ed., Awrāq Lubnāniyya 3 (Lebanese Papers 3) (al-Hāzimiyya: Dār al-Rā'id al-Lubnānī, 1957), $86-7$.

${ }^{37}$ Havemann, Rurale Bewegungen, 396-7.

${ }^{38}$ Touma, Paysans et institutions féodales, 1:179, 2:818.

${ }^{39}$ Havemann, Rurale Bewegungen, 245; Charles de Clercq, Histoire des conciles d'après les documents originaux, vol. 11 (Paris: Letouzey et Ané, 1949), 215, 256, etc.; Shidyāq, Akhbār al-a yān, 401; Winter, Shiites of Lebanon, 162.
} 
via the Maronite Bishop Yūsuf Istifān. ${ }^{40}$ The pact of Bsha la appointed a wakil to be responsible for the village's 'commitments and losses' of money and men to the commoner cause. ${ }^{41}$

Most striking, though, is the novel constellation of terms used to refer to the assembly or movement: the 'ammiyya (commoners, commonalty), the jumhūr ('all of', mass), and their șälih (good, interest). These terms were indeed taking on new meanings through the events of 1821, but these can be explained as innovations from within the existing local political culture. Jumhür had long been in use to indicate the totality or overwhelming majority of a group, often assembled together for some collective action such as a petition or pact. ${ }^{42}$ Jumhūr could also mean a 'mass' or 'crowd', particularly an armed one. ${ }^{43}$ The chronicler Haydar al-Shihābī, a member of Emir Bashīr's retinue in 1821, often refers to the rebels simply as 'those jumhürs', apparently grasping at a term that could describe this new presence on a political scene long dominated by a handful of notable houses. $^{44}$

The term 'àmmiyya (sometimes spelt 'ammiyya) can likewise be seen taking on new connotations. In documents and contemporaries' accounts of 1821, as well as of 1840, it is sometimes used simply to mean 'commoners': the chronicler Țannūs al-Shidyāq often employs 'āmmiyya with verbs and pronouns in the plural. ${ }^{45}$ Yet his consistent use of this word to describe the assembled commoners also registers their distinctive identity as a non-elite grouping. This foreshadows the term's emergent sense as a more or less organized collectivity, a 'commonalty', as expressed in the pact of Bsha'la village:

we whose names are listed below, all of the people of Bsha' la as a whole (bi-wajh al- 'umūm), great and small, have been pleased to give obedience and entrust ourselves and our money, and whatever may be demanded of us in the matter of what concerns the good of the commonalty (sālih al- 'ammiyya); appointing as a representative our cousin Ṭannūs al-Shidyāq Nașr ... for our own good (șälih) and that of all the assembled commoners (li-l-jumhür al-'ammiyya). ${ }^{46}$

This usage prefigures the later adoption of 'ammiyya as the accepted term for the two 1821 leagues - 'the 'àmmiyya of Anțalyās' and 'the 'ämmiyya of Liḥid' - as well as for later popular movements. ${ }^{47}$ The term șa $a$ lih̆, also used in the pact, had previously been used to express the interest' or 'good' of a particular group: peasants swearing loyalty to a lord had promised to 'strive in his interest (șālih $)^{\prime} .{ }^{48}$ The novelty was in using it in conjunction with 'ämmiyya and jumhūr, to refer to the 'interest' of the commoner collectivity, not of a notable faction.

\footnotetext{
${ }^{40}$ Shidyāq, Akhbār al-a'yān, 401.

${ }^{41}$ Havemann, Rurale Bewegungen, 396-7 (translation 106-8).

${ }^{42}$ For examples, see Chevallier, La Société du mont Liban, plate XVII; Mīkhā’īl Burayk, Tārīkh al-Shām (1720-1782): yatadammanu tārīkh al-Shām wa-Filasținn wa-Lubnān (History of Damascus (1720-1782), Containing the History of Syria, Palestine and Lebanon) (Harīṣā: Mațba at al-Qiddīs Būlus, 1930), 121.

${ }^{43} Z$ Zughayb, 'Awdat al-Nașārā, 12; Asad Rustum, al-Mahfūzāt al-Malikiyya al-Miṣriyya: bayān bi-wathā'iq al-Shām wa-mā yusā 'idu 'alā fahmi-hā wa-yūẹihu maqāsid Muhammad 'Alī al-Kabīr (The Egyptian Royal Archives: A List of the Documents on Syria, with What Will Aid in Understanding Them and Shed Light on the Intentions of Mehmid Ali the Great) (Beirut: American Press, 1940), 4:410-12 (doc. 6377).

${ }^{44}$ Shihābī, Lubnān, 3:685-9; see also 692-3.

${ }^{45}$ Shidyāq, Akhbār al-a yān, 95, 119-21, 146-7, 170, 177, 401-11, 458-63. See also letters from Ighnātiyūs Sarkīs, 9 and 25 April 1821: Yūsuf Ibrāhīm Yazbik, ed., A wrāq Lubnāniyya 2 (al-Ḥāzimiyya: Dār al-Rā’id al-Lubnānī, 1956), 416; SC Ospizio 2, 433r.

${ }^{46}$ Havemann, Rurale Bewegungen, 396-7.

${ }^{47}$ Hattūnī, Nabdha tārīkhiyya, 242; Fā’iz, Abū Samrā Ghānim, 53; Rustum Bāz, Mudhakkirāt Rustum Bāz (Memoirs of Rustum Bāz) (Beirut: al-Jāmi'a al-Lubnāniyya, 1955), 17; Kattar, 'Les insurrections paysannes', 681; Rustum, al-Mahfūzāt al-Malikiyya, 4:416-17 (doc. 6390).

${ }^{48}$ Touma, Paysans et institutions féodales, 2:812.
} 


\section{'Are Christians only for paying piasters?'}

If the ideas and terms which some have attributed to French inspiration have more probable roots in local political culture, there remains another possible source of ideological inspiration: Greece. The outbreak of the war which would lead to an independent Greek state was actually simultaneous with the 1821 Lebanese leagues. The French consul at Tripoli could write of both peasant leagues and Greek risings as part of 'l'agitation générale', equally 'symptômes de guerre, de Révolte et d'anarchie'. ${ }^{49}$ Early Greek revolutionaries dreamed of a rebellion spanning the Balkans and the Hellenic diaspora, and attempts were in fact made to draw Mount Lebanon into the struggle. In 1820 or early 1821, when the Greek leader Alexandros Ypsilantis was in Odessa preparing for the Balkan expedition which would initiate the war, he reportedly had tentative contacts with Mount Lebanon via a Macedonian merchant. ${ }^{50}$ Yet these contacts were not with the commoner rebels but with Emir Bashïr himself; and they had no immediate consequences, since in the spring of 1821 the commoners forced Emir Bashir into exile, and by July Ypsilantis was defeated and in an Austrian gaol. ${ }^{51}$ When contacts were resumed in $1825-26$ between the now-restored Emir Bashir and the provisional Greek government in Nafplio, the only upshot was an unofficial raid on Beirut by some fifteen ships. ${ }^{52}$ The notion of a Lebanese 'second front' in the Greek war remained stillborn.

On the other hand, the main dynamic of the Greek war, whatever the Jacobin or liberal inspirations of some of its instigators, soon became that of a Christian rebellion against the Muslim 'Turks'. We might be tempted to see in Mount Lebanon a close analogue: a Christian popular rising against Muslim or Druze rule, exacerbated by the Christian-Muslim tensions bred by the Greek rebellion. The notion resonates strongly with subsequent Lebanese politics, which took a marked sectarian turn from the 1840s onwards.

The leagues of 1821 were certainly made up of Maronite Christians, and the clergy played a part in organizing them; the French consul of Tripoli called the first league's titular leader 'General of all the Christians of Lebanon and Anti-Lebanon ${ }^{53}$ Their cause was based, in part, on specifically Christian resentments. The Druze-dominated districts of southern Mount Lebanon had been sheltered from Abdallah's tax demands, and the burden pushed onto the Christians of the north alone, and their clergy and monasteries. ${ }^{54}$ As well as causing material hardship, unequal taxation had implications for the relative status of communities. All non-Muslims in Ottoman lands were supposed to pay an extra poll tax for their 'protection' by arms-bearing Muslims, but this had always been difficult to extract effectively from the independent, armed Christians of Mount Lebanon. ${ }^{55}$ New taxes for Christians alone could look like an attempt to reduce them to subject, non-martial status: as a poet put it, 'Are Christians only for paying piasters, and Druze for fighting with curved

\footnotetext{
${ }^{49}$ Reynault to Pasquier, 27 August 1821, Tripoli, AE 346CCC/17.

${ }^{50}$ Dimitrios Ypsilantis to Emir Bashīr, 15 June 1825, cited in Emmanuel Protopsaltis, 'Authairetos Epidromi Hellinon kata tou Libanou (1826)' ('An Arbitrary Raid of the Greeks on Lebanon (1826)'), Athena 58 (1954): 258-9; Richard Stites, The Four Horsemen: Riding to Liberty in Post-Napoleonic Europe (Oxford: Oxford University Press, 2014), 198-9.

${ }^{51}$ Stites, Four Horsemen, 208.

${ }^{52}$ See Protopsaltis, 'Authareitos Epidromi Hellinon', 243-77; Spyros Loukatos, 'Prospatheiai Hellino-Syrolibanikis Symmachias kata ton Tourkon kata tin Hellin. Epanastasin (1822-1828)' ('Attempts at a Greek-Syrian-Lebanese Alliance Against the Turks During the Greek Revolution (1822-1828)'), Mnemosyne 3 (1970-1): 329-94. I will examine these contacts further in a forthcoming article in Historein 21 (2022).

${ }^{53}$ Martin (Journal no. 4), 2 April 1821, AE 306CCC/27. Father Ighnātiyūs Sarkīs called him 'head of the league of Christians': Yazbik, ed., Awrāq Lubnāniyya 2, 417. The title 'General of the Christians' would appear again in 1840: Shidyāq, Akhbār al-a yān, 458.

${ }^{54}$ See 'N Latoofs Relation of the Rebellion', 2 January 1828, Eli Smith Arabic Papers (ABC50), 2/14, 1r, cols. 1-2, Houghton Library, Harvard University; letter from Ighnātiyūs Sarkīs, SC Ospizio 2, 433r.

${ }^{55}$ Chevallier, La Société du mont Liban, 111-12; Polk, Opening of South Lebanon, 43. See also Touma, Paysans et institutions féodales, 2:642-5; Amnon Cohen, Palestine in the 18th Century: Patterns of Government and Administration (Jerusalem: Magnes Press, Hebrew University, 1973), 249-56.
} 
swords? ${ }^{56}$ Outbreaks of violence between Druze and Christians over taxes were reported in central Mount Lebanon in May 1821. ${ }^{57}$ Further north, there were older precedents for a quasireligious insurrection, in the 1759 rising of Christians against their Shia Muslim lords, which had, by 'Aynțūrīnī's account, quickly turned into an assault on Shia in general. ${ }^{58}$

A rising of Christians, led partly by the clergy and contemporary with the Greek rebellion, might thus appear to offer propitious circumstances for a sectarian outbreak. The repercussions of the Greek war in Syria, as across the Ottoman empire, certainly increased tensions between Muslims and Christians. After the Ottoman authorities hanged the Greek Orthodox Patriarch of Istanbul on Easter Sunday 1821, governors elsewhere hastened to remind Christians of their subject status. In Damascus, old sumptuary laws were re-enforced; along the Syrian coast, Abdallah Pasha imposed a poll tax on Christians, fined merchants, and expelled some from Tripoli; more fled into Mount Lebanon. ${ }^{59}$ Abdallah attempted to disarm Christians at Sidon in April, and at Tripoli in July. ${ }^{60}$

Such acts may have added to Mountain commoners' feeling that extra taxation was an attempt to reduce them to subject status. And this may indeed have formed part of Abdallah Pasha's intention, spurred not by Greek events but (one chronicler suggests) by his contacts with plebeian Sufi circles in Acre. ${ }^{61}$ Only around the cities and the coast, though, could Abdallah impose his measures directly. In the Mountain, beyond the range of his troops, both Abdallah's tax demands and the commoner leagues entered into a pluralistic politics of elite factions, which militated against any simple polarization of Christians against Muslims or Druze. The first league of commoners negotiated directly with Abdallah, and he reciprocated. ${ }^{62}$ After forcing Emir Bashīr from power, they made a pact with his cousins and rivals, the emirs Hasan and Salmān (and the Druze elite faction which supported them), according to which they would not pay extra taxes. Abdallah endorsed this, investing Hasan and Salmān as joint emirs - though he also arranged for their public conversion to Islam. ${ }^{63}$ The latter was probably meant as a token of Ottoman loyalty in the context of the Greek revolt, yet the assembled Christian commoners do not appear to have objected, since they then accompanied the new emirs (along with their Muslim teacher and a regiment of Abdallah's troops) to the capital, Dayr al-Qamar. ${ }^{64} \mathrm{~A}$ few months later, when the two officially Muslim emirs failed to deliver the taxes, Abdallah accepted the return of Emir Bashir (widely believed to be a Christian), who concluded another pact with the Christian and Druze elite and commoner leaders of the north-central districts. When the second commoner league of Lihfid arose, among the districts further north excluded from this pact, Emir Bashïr sent the Druze troops of his ally Bashīr Jumblāt to suppress it. The Christian commoners called on the (ineffective) aid of both the emirs Hasan and Salmān and their Druze supporters, and the Shia Muslim elite of the far north, their ancestors' former lords. ${ }^{65}$

Despite the inherent sectarian potential of an all-Christian league with clerical leadership, the commoner leagues of 1821 seem - unlike their successors later in the century - to have largely

\footnotetext{
${ }^{56} \mathrm{Ma}$ ' lūf, 'al-Azjāl', 120; see also letter from Ighnātiyūs Sarkīs, in Yazbik, ed., Awrāq Lubnāniyya 2, 416; Harik, Politics and Change, 209, 220.

${ }^{57}$ Martin (Journal no. 5), 6 May 1821, AE 306CCC/27.

58' Aynțūrīnī, Mukhtașar, 134.

${ }^{59}$ Mishāqa, Murder, Mayhem, 121-2; Martin to de Viella, 15 June 1821, Seyde [Sidon], 633PO/1/85, Centre des Archives Diplomatiques de Nantes (hereafter cited as CADN); Aubin to Martin, 31 May, 29 June 1821, CADN 633PO/1/86; Regnault to Pasquier, 15 July, 27 August 1821, AE 346CCC/17.

${ }^{60}$ Martin to Ruffin, 25 April 1821, Acre, CADN 593PO/1/38; Regnault to Pasquier, 27 July 1821, AE 346CCC/17.

${ }^{61}$ Mishāqa, Murder, Mayhem, 106-9.

${ }^{62}$ Shihābī, Lubnān, 3:659; Shidyāq, Akhbār al-a yān, 401; letter from Ighnātiyūs Sarkīs, in Yazbik, ed., Awrāq Lubnāniyya 2 , 417; 'N Latoofs Relation', 1r, cols. b-c.

${ }^{63}$ Ibid., 1r, col. c; Shidyāq, Akhbār al-a'yān, 401-2.

${ }^{64}$ Shidyāq, Akhbār al-a yān, 402; letter from Ighnātiyūs Sarkīs, in Yazbik, ed., Awrāq Lubnāniyya 2, 417.

${ }^{65}$ Shidyāq, Akhbār al-a yān, 407-9, 411; Shihābī, Lubnān, 3:685-6. Abdallah Pasha also firmly opposed this second league: see his menacing proclamation in Shihābī, Lubnān, 3:691-3.
} 
avoided being drawn into a polarization along religious lines. The Greek events clearly affected those in Mount Lebanon to some degree, but largely by way of the Ottoman state and its anxieties. The direct effects of the Greek war began to be felt along the Lebanese coast only after the Lihfid rising had been suppressed in November 1821, with the flight of Tripoli's Greek Orthodox Christians into the Mountain and frequent raids on the coast by Greek corsairs. ${ }^{66}$ Soon thereafter, Abdallah Pasha himself would enter into rebellion against the Ottoman state, and receive aid from the corsairs while besieged in his fortress of Acre. ${ }^{67}$ In 1826, Emir Bashīr's renewed contacts with the Greeks led only to the brief assault on Beirut, which he refused to support. ${ }^{68}$ Neither Bashir nor other Lebanese seem to have been inspired by visions of pan-Ottoman revolution, and the pluralistic politics of Mount Lebanon did not yet lend themselves to a sharp polarization between Christian and Muslim.

\section{Extracting blood and treasure}

Instead of French revolutionary ideology or a Greek-style polarization between Christians and Muslims, the Lebanese events of 1821 seem to be a case of innovation from within the terms of a local political culture. This culture involved factional bargaining among a pluralistic elite, backed up with violence but also employing oaths and written pacts (however frequently broken). In 1821, a commoner collectivity, the jumhür 'ammiyya, broke into this hitherto elite sphere, blending some of its forms (loyalty oaths, delegates, written pacts, and correspondence) with village-level practices (village assemblies, collective agreements) to forge unity among commoners and to conclude agreements with other factions. If ideological influence is ruled out, how do we explain its simultaneity and parallels with the broader age of revolutions?

The possibility of simple coincidence cannot be excluded. But I will suggest here that, while ideological connections do not seem plausible, at the level of more material factors it is possible to trace common causes lying behind the Mount Lebanon leagues and other revolutions. To examine these, we must turn to the original casus belli of the 1821 events: Abdallah Pasha's excessive demand for taxes. This belongs to a larger pattern: excessive tax demands from previous governors had also provoked smaller rebellions by Lebanese commoners in 1800 and 1805 . It seems plausible to link these to the intensification of the extractive power of the state in the region.

The eighteenth century had seen a struggle among local elites and corporate groups to extract revenue from the increasingly profitable commercial economy of the south-east Mediterranean: silk from Mount Lebanon, tobacco from coastal Syria, cotton from Acre and Egypt, rice from Egypt, grain from inland Syria, soap and olive oil from Palestine, and coffee entering Egypt from Yemen. ${ }^{69}$ Over the course of the century, the power of the central Ottoman state had receded, allowing local magnates in Syria and Egypt, as elsewhere, to centralize and extend their power. ${ }^{70}$ The rulers of Acre, Zāhir al- 'Umar and later Jazzar Pasha, were especially successful: monopolies and close ties to European merchants allowed them to concentrate revenue and military force in their own hands and extend their domains, supplanting other elites. ${ }^{71}$

\footnotetext{
${ }^{66}$ Regnault to Pasquier, 10 November 1821, 31 January 1822, 1 February 1823, and 23 August 1823, AE 346CCC/17.

${ }^{67}$ Regnault to Pasquier, 28 February 1822, AE 346CCC/17.

${ }^{68}$ Loukatos, 'Prospatheiai Hellino-Syrolibanikis Symmachias'; Guys to Comte de Damas, 4 April 1826, Beyrouth, and attached report, CADN 92PO/A/10.

${ }^{69}$ André Raymond, Artisans et commerçants au Caire, au XVIIIe siècle (Damascus: Institut Français de Damas, 1973), 1:184-91; Beshara Doumani, Rediscovering Palestine: Merchants and Peasants in Jabal Nablus, 1700-1900 (Berkeley: University of California Press, 1995).

${ }^{70}$ Suraiya Faroqhi, ed., The Cambridge History of Turkey, Vol. 3: The Later Ottoman Empire, 1603-1839 (Cambridge: Cambridge University Press, 2006), part III, 'The Centre and the Provinces'.

${ }^{71}$ Thomas Philipp, Acre: The Rise and Fall of a Palestinian City, 1730-1831 (New York: Columbia University Press, 2001); Cohen, Palestine in the 18th Century.
} 
These magnates' struggles constituted, in effect, an intra-imperial competition between local military-fiscal regimes, which could interact with the struggle between the central Ottoman state and other empires. In 1771, as the Ottomans were engaged in a costly war with Russia, the Mamluk magnates of Egypt invaded Syria in alliance with Zāhir al- 'Umar, and explored a possible Russian alliance. ${ }^{72}$ In 1798-99, French revolutionary forces invaded Egypt and Syria, facing British and Ottoman opposition and drawing regional potentates - the Egyptian Mamluks, Jazzar Pasha, Emir Bashīr - into the struggle. In its aftermath a new force arose, as the Rumelian soldier Mehmed Ali succeeded in making himself master of Egypt. The wars of the late eighteenth and early nineteenth centuries placed great burdens on Ottoman state finances, spurring military and administrative reform at both central imperial and local magnate levels. ${ }^{73}$ There was an uneven but marked intensification of the military-fiscal state across the south-east Mediterranean, by way of the tight monopolies and mercenary armies of the rulers of Acre, attempts by Emir Bashï to tighten his control over Mount Lebanon in the 1820s, and ultimately Mehmed Ali's novel extractive regime in Egypt and the conscript army he would use to invade Syria in $1831 .^{74}$

Rulers concentrated power and profit within a narrower circle: their competition led to frequent wars as well as increased demands for revenue, and both bore heavily on the common people. Around 1791, a farmer-poet in Mount Lebanon wrote:

Three years have passed, and all three of them cursed:

Extortion, war, deep-rooted hunger - these are stern trials. ${ }^{75}$

In addition, these were years of frequent high prices, dearth, and locust attacks. ${ }^{76}$ These trials perhaps seemed worse by contrast with new opportunities offered by the expanding commercial economy: the 1790s poet writes of falling into penury from relative prosperity. In a period of rising prices and inflation, producers could do well if taxes were paid in cash at historic fixed rates. ${ }^{77}$ But rulers did their utmost to extract revenue from the system, Jazzar Pasha gaining a reputation for especial rapacity. ${ }^{78} \mathrm{He}$ and other military-fiscal centralizers weakened or destroyed old intermediary elites, replacing them with new ones: chancellors and bankers, men adept in the manipulation of money and paper but whose legitimacy was often unclear. ${ }^{79}$ The poet of 1791 went on to blame the emir's wealthy Christian chancellor:

If only Jad'ūn Āghā were dead! ...

Everyone curses him, even the monks and the pious. ${ }^{80}$

\footnotetext{
${ }^{72}$ These negotiations drew in Emir Bashïr's predecessor: see Paul du Quenoy, 'The Russian Occupation of Beirut, 1773-1774', Russian History 41, no. 2 (2014): 128-41.

${ }^{73}$ Şevket Pamuk, A Monetary History of the Ottoman Empire (Cambridge: Cambridge University Press, 2000), 188-204; Virginia H. Aksan, Ottoman Wars 1700-1870: An Empire Besieged (London and New York: Routledge, 2013), esp. chaps. 5-8; Cohen, Palestine in the 18th Century, 183-5.

${ }^{74}$ Cohen, Palestine in the 18th Century, 282-92; Harik, Politics and Change, 229-35; Khaled Fahmy, Mehmed Ali: From Ottoman Governor to Ruler of Egypt (Oxford: Oneworld, 2009).

${ }^{75}$ 'İsā Iskandar Ma 'ūf, ed., 'Zajaliyya fī waṣf al-ghalā' wa-l-jaw' wa-l-ḍị' ('A Popular Poem Describing High Prices, Famine, and Hardship'), al-Mashriq 18 (1920): 341.

${ }^{76}$ See, for instance, 'Aynțūrīnī, Mukhtașar, 166-7, 174; Shihābī, Tārīkh Aḥmad Bāshā al-Jazzār, 477; Fahd, Tārīkh al-rahbāniyya, 5:453-4.

${ }^{77}$ Rulers would justify tax increases in these terms: Shihābī, Lubnān, 3:691-3.

${ }^{78}$ Cohen, Palestine in the 18th Century, 199-200, 205, 233, 244-9.

${ }^{79}$ Thomas Philipp, The Syrians in Egypt, 1725-1975 (Stuttgart: Franz Steiner, 1985), 25-34; Harik, Politics and Change, 167-99.

${ }^{80} \mathrm{Ma}$ 'lūf, 'Zajaliyya', 341.
} 
Non-elite contemporaries elsewhere in Syria evoked a similar atmosphere of instability and conflict; as different elites rose and fell, contrasts between hardship and prosperity became more flagrant, and legitimacy was called into question. ${ }^{81}$ Such polarities may help us to explain why certain peasant producers in north-central Mount Lebanon would themselves claim a place in the competition over tax revenue, previously the domain of the elite.

These south-east Mediterranean developments fit into a far broader pattern of increasing military spending and state centralization. Behind it lay, most probably, the increase in monetizable wealth produced by commercialization and 'industrious revolutions' across Eurasia and the Atlantic world, which raised the stakes of inter-state competition. Christopher Bayly places Jazzar Pasha and the Mamluks of Egypt, along with Mysore and the Maratha state in India, in a group of small, aggressive polities emerging from within the weakening Muslim empires of Asia; we might add further examples such as Nguyen Vietnam. ${ }^{82}$ In the Euro-Atlantic nexus including, Toby Green argues, West African polities - a quickening tempo of military competition pushed states into autocratic reforms designed to extract more resources from populations, provoking political crises. ${ }^{83}$ The major theme was that of Franco-British competition; lesser powers also attempted to keep up, enacting centralizing reforms which provoked rebellions from the Andes (Tupac Amaru, the Comuneros) to southern Russia (Pugachev's rebellion of 1773-75, in the wake of the Russo-Ottoman war). ${ }^{84}$ The culmination of this process was the French Revolution and the wars that followed, which led to an unprecedented expansion of military-fiscal power, especially British, worldwide, impacting non-European polities and peoples which had not been deeply affected by the earlier dynamic. ${ }^{85}$

\section{Logics of response}

Increasing tax demands thus seem to have originated in a dynamic of military-fiscal competition, which ranged across continents. But the pressures this generated operated on a set of very different, and often separate, political cultures, from the Euro-Atlantic nexus to West Africa to the Ottoman empire. Where ideological links are absent, how can we explain the fact that some at least of these cultures responded in what look like parallel ways, involving (for instance) 'bottom-up' political organization by the common people, or formal 'constitution-like' negotiated pacts?

Let us first examine the nature of the response in Mount Lebanon in 1821, when Abdallah Pasha's tax demand exerted a pressure on the emirate. Emir Bashīr al-Shihābì was adept at the delicate and sometimes bloody game of Mount Lebanon politics. This involved essentially balancing the tax demands of the Pasha of Acre against the reluctance to pay of various factions of the Mountain tax-farming elite, while retaining as much revenue as possible for himself. The emir had to avoid alienating either too many of the elite, who provided him with armed support, or the pasha himself, who could side with another faction and elevate another male member of the Shihābī family as emir. ${ }^{86}$ His qualified independence reflected the economic and military balance of power between the Mountain and the coast and plains. The Mountain was extremely hard to subdue by outside force, but it was sufficiently dependent on outside trade - not least for its food -

\footnotetext{
${ }^{81}$ See chronicles cited in Dana Sajdi, The Barber of Damascus: Nouveau Literacy in the Eighteenth-Century Ottoman Levant (Stanford: Stanford University Press, 2013), 19-20, 135-6, 151.

${ }^{82}$ C. A. Bayly, Imperial Meridian: The British Empire and the World, 1780-1830 (London and New York: Longman, 1989), $35-51$.

${ }^{83}$ Adelman, 'Age of Imperial Revolutions', 323-7. Green, Fistful of Shells, chaps. 7 and 10.

${ }^{84}$ Bayly, Birth of the Modern World, 88-106; Bayly, Imperial Meridian, 54-76.

${ }^{85}$ Bayly, Imperial Meridian, chaps. 7 and 8; Fullagar and McDonnell, eds., Facing Empire.

${ }^{86}$ Harik, Politics and Change, chap. 3, 37-73.
} 
that good relations were necessary in the long run. ${ }^{87}$ A powerful governor like Jazzar could play off elite factions against each other, securing ever-increasing promises of revenue from weak emirs. ${ }^{88}$ A powerful emir, as Bashïr became through the 1820s and 1830s, could build up his own militaryfiscal regime and increase his independence of the Ottoman governors: armed Lebanese peasants could be a formidable force in regional wars. ${ }^{89}$ A sufficiently powerful alliance of the great taxfarming families, meanwhile, could impose its own candidate as emir. ${ }^{90}$

Success was never guaranteed: Emir Bashïr had been deposed a few times between his first appointment as emir in 1788 and $1821 .{ }^{91}$ A particularly excessive tax demand could put a major strain on the delicate system. How did the emir respond when faced with Abdallah's exorbitant claim in 1821? First he stalled. He might have considered resisting - as he would do in 1830-31. ${ }^{92}$ But faced with Abdallah's seizure of hostages, mobilization of troops, and parleys with his rivals, he had to sign a promissory note for the taxes. He then borrowed from moneylenders and his rich ally Bashīr Jumblāt, but this could only be a short-term solution. ${ }^{93}$ He could, of course, have demanded cash from others of the tax-farming elite, but he could not afford to alienate too many of the allies on whom he depended for military support. (Their coffers, besides, had reputedly been emptied by the rapacious demands of Jazzar Pasha. ${ }^{94}$ ) Christians, at any rate, would claim that Emir Bashīr was unwilling or unable to impose extra taxes on the southern districts because these were the domains of Bashīr Jumblāt and other Druze lords on whom his power depended. ${ }^{95}$ The Christian peasants of the northern districts, however, were unprotected by any important elite group: since the expulsion of the Shia lords, their taxes were farmed via petty Christian village shaykhs.

The imposition of the extra taxes on the northern commoners and monasteries provoked a temporary breakdown of the elaborate system of clientship whereby commoners were incorporated into competing elite factions. Instead of a 'negotiated' politics (in Yaycioglu's terms), the emir's 'top-down' imposition of taxation was met by a novel, 'bottom-up' mode of organization. The fact that the northern peasants were protected by no major elite faction opened the way for them to organize as a commoner collectivity instead. The local elite, of clerics and village shaykhs, was relatively humble and unintegrated into the politics of the Mount Lebanon emirate. They were unable either to offer the commoners effective paternalist protection or to suppress their risings if indeed they wanted to. ${ }^{96}$ Village shaykhs after the second 1821 rebellion would claim that they had been compelled to go along with it, but may have been covering for a more active sympathy. One, 'Aynțūīinī, was killed for taking part, as was at least one priest. ${ }^{97}$ In any case, the local shaykhs could not or would not provide Emir Bashïr with enough military force to suppress the rising, and he had to call on Bashīr Jumblāṭ s Druze retainers. ${ }^{98}$

\footnotetext{
${ }^{87}$ Chevallier, La Société du mont Liban, 42-4, 81; Polk, Opening of South Lebanon, 72-82. See also Ma 'lūf, 'Zajaliyya', 344; Mishāqa, Murder, Mayhem, 50-1.

${ }^{88}$ Philipp, Acre, 64-5; Chevallier, La Société du mont Liban, 116.

${ }^{89}$ Rustum, Bashìr bayna al-Sultān wa-l- 'Azìz, 1:32-5, 40, 64, 77-9, 81-3.

${ }^{90}$ As in 1770: see Shihābī, Lubnān, 1:88.

${ }^{91}$ See Harik, Politics and Change, 58.

${ }^{92}$ Chevallier, La Société du mont Liban, 102-3.

${ }^{93}$ Shihābī, Lubnān, 3:655-9; Shidyāq, Akhbār al-a yān, 2:400.

${ }^{94}$ Chevallier, La Société du mont Liban, 123-6, 147; Shihābī, Lubnān, 2:432.

${ }^{95}$ 'N Latoofs Relation', 1r, col. b; letter from Ighnātiyūs Sarkīs, in Yazbik, ed., Awrāq Lubnāniyya 2, 416. See also John Lewis Burckhardt, Travels in Syria and the Holy Land (London: John Murray, 1822) 196-7; Harik, Politics and Change, 208-9; Polk, Opening of South Lebanon, 47-8, 81.

${ }^{96}$ Shahwān, 'Ḥayāt Mattā Shahwān', 8, claims that the extra taxes threatened to ruin those 'of middling condition' as well as the poor.

${ }_{97}^{97 b i d ., ~ 11-13 ; ~ S h i h a ̄ b i ̄, ~ L u b n a ̄ n, ~ 3: 689-90 ; ~ M i s h a ̄ q a, ~ M u r d e r, ~ M a y h e m, ~ 129 ; ~ H a t t u ̄ n i ̄, ~ N a b d h a ~ t a ̄ r i ̄ k h i y y a, ~ 246 . ~ B i s h o p ~ Y u ̄ s u f ~}$ Isțifān is also said to have been poisoned by Emir Bashīr two years later: Hattūnī, Nabdha tārīkhiyya, 206-7; Harik, Politics and Change, 219.

${ }^{98}$ Shihābī, Lubnān, 3:684-91; Shidyāq, Akhbār al-a yān, 146-7, 407-11.
} 
The presence of an accessible, co-optable elite helps explain how the commoner movement could access elite political forms such as writing, pacts, and delegates - and hence why northcentral Mount Lebanon in particular should have seen the emergence of this novel political form. Similar factors probably favoured the emergence of other episodes of 'commoner' selforganization during the age of revolutions. Yet behind such episodes, I suggest, lay generalizable connections between 'top-down' military-fiscal competition and the mobilizations of 'common people', which operated across what were often very localized and distinctive political cultures. ${ }^{99}$ Three logics seem to derive from the dynamic of military-fiscal competition itself. Adelman describes one: the imperial drive to compete for 'frontier' lands, particularly in North America, which drew indigenous peoples inhabiting such lands into the revolutionary conjuncture. ${ }^{100}$

A second logic was military: imperial competition placed military personnel at a premium, and they too had to come from part of the common people. Even before the revolutionary crises, this seems to have placed some 'egalitarian' groups of soldiers - Muslim tribesmen in India, Janissaries in Istanbul, armed bands in the Ottoman Balkans - in a strong political position. ${ }^{101}$ The need for military or quasi-military personnel then increased dramatically in the revolutionary crises and wars themselves. This could lead to new political compacts linking citizens' rights to national military service; ${ }^{102}$ these, in turn, might include previously excluded groups, such as slaves freed in return for military service. ${ }^{103}$ Similarly, in both urban and rural 'revolutionary' politics, crowds and bands of common people, sometimes armed, became major forces; even where these operated in the interest of elite factions, they might command rewards for their service. ${ }^{104} \mathrm{We}$ can see a logic of this type, perhaps, behind the growing role of Lebanese troops in regional wars, and the Christian commoners' demand to be recognized as fit, like the Druze, to 'fight with curved swords'.

Most evident in the Lebanese case is a third logic, of fiscal extraction. The needs of military competition pushed states or state-like regimes into more ambitious modes of extracting resources from populations. Intermediary elites or corporate groups, part of an older 'negotiated' or paternalist order, were stripped away and replaced by new moneyed men and officials who, like the emirs' chancellors, often lacked the legitimacy of the old elites. ${ }^{105}$ The extractive power of state or magnate came increasingly to confront, in bare, unmediated form, the common people - who were, as Rediker and Linebaugh remind us, the producers of the wealth that was at stake in military-fiscal competition. ${ }^{106}$ This newly stark opposition could lead these people towards organizing themselves, not as members of corporations or adherents of elite factions - entities no longer capable of protecting them - but in more general categories such as 'commoners' or 'citizens'.

These three logics did not of course operate uniformly or with equal force everywhere; nor did they lead to the same outcomes. Exactly where and how they provoked confrontations between 'top-down' and 'bottom-up' politics was certainly shaped by local political traditions as well as sheer contingency. Nothing in these general trends could predict that a newly appointed young pasha, perhaps moved by Sufi zeal, would decide to demand exorbitant taxes in 1821, or that the balance of Lebanese politics at that moment would lead to their being imposed on the

\footnotetext{
${ }^{99}$ Joanna Innes and Mark Philp, eds., Re-Imagining Democracy in the Age of Revolutions: America, France, Britain, Ireland, 1750-1850 (Oxford: Oxford University Press, 2015), 7 and passim; Klooster, Revolutions in the Atlantic World, 2, 162-5.

${ }^{100}$ Adelman, 'Age of Imperial Revolutions', 324. See also Alfred Rieber, The Struggle for the Eurasian Borderlands: From the Rise of Early Modern Empires to the End of the First World War (Cambridge: Cambridge University Press, 2014).

${ }^{101}$ Bayly, Imperial Meridian, 35-59; Yaycioglu, Partners of the Empire, 30-4; Frederick F. Anscombe, 'The Balkan Revolutionary Age', Journal of Modern History 84, no. 3 (2012): 572-606.

${ }^{102}$ See David A. Bell, 'Armed Forces', in Re-Imagining Democracy in the Mediterranean, ed. Innes and Philp, 253-70.

${ }^{103}$ Klooster, Revolutions in the Atlantic World, 43-4, 163-4.

${ }^{104}$ Ibid., 19-21, 59-61, 67-8, 126; Stites, Four Horsemen, 34-7, 70, 90-1, 94-6, 125-6, 135-9, 211-13, 251-2.

${ }^{105}$ See e.g. Klooster, Revolutions in the Atlantic World, 18-19, 45-7, 122-7.

${ }^{106}$ Rediker and Linebaugh, Many-Headed Hydra, chap. 2.
} 
north-central districts. But we can suggest that many broader similarities between widely separated political developments in the age of revolutions can be attributed to such logics, arising from the central dynamic of competing military-fiscal regimes.

\section{Renegotiation}

The hegemony of the bottom-up organization of plebeians and commoners rarely lasted long: elite rule soon reasserted itself. Yet it did not always do so simply in the old forms of top-down politics. Elite groups regained power partly via a process of negotiation and co-optation, in the course of which they blended the innovations of bottom-up politics with older political forms. This process, too, is visible in Mount Lebanon.

The politics of the emirate had traditionally been the business of emirs and shaykhs, not of commoners. When one of Emir Bashīr's rival emirs asked some Druze shaykhs to join him and the commoners of the Jbayl district, they replied: 'we will not be led by the Christian commoners of that country: it would be a disgrace for us'. ${ }^{107}$ It was probably to gain respectability in the face of elite attitudes like this that the first 1821 movement appointed a man of rank as titular head. ${ }^{108}$ But the complex, divided nature of political authority in the Mountain meant that the elite did not instantly form a common front against the peasant collectivity: many were prepared to negotiate or ally themselves with them. Rival Shihābi emirs, their Druze supporters, and the Shia lords of the north were prepared to collaborate actively, and Abdallah Pasha was prepared to negotiate with them. Emir Bashir had previously made a written alliance with the anti-tax rebels of 1800 , securing their aid for his return to power. ${ }^{109}$ In the summer of 1821 , some of his faction seem to have made pacts with commoners which used the new language of popular interests and representation, alongside an older vocabulary of obedience. A pact sworn by a single family in July 1821 to a shaykh loyal to Emir Bashīr echoes the language of the commoner pacts: 'we will be with the whole of the blessed commonalty (jumhür al- 'ammiyya) ... we will consider the good of the populace (șälih al- jumhür)'. ${ }^{110}$

But the most elaborate covenant to come out of the interaction between elites and commoner movements was made in June 1821. After returning to the Mountain from his brief exile, Emir Bashīr gathered notables at the village of Sumqāniyya (where in 1697 the Druze elite is said to have met to elect his Shihābi ancestor as emir). Here he had a pact signed by representatives of the eight leading families of the tax-farming elite, plus 'all the people' of the Matn, Shüf, and Gharb regions of central-southern Lebanon. We should be sceptical as to the 'all': most chronicle accounts refer mainly to shaykhs or notables as participants. But they perhaps included some leaders of the first commoner league of Anțalyās; its titular head, Shaykh Faḍl al-Khāzin, signed. ${ }^{111}$

The Sumqāniyya pact notes that 'Circumstances in the land, the overturning of its condition and the dissension among its great men', are bringing about 'destruction and the ruin of the country'. Hence the signatories, the 'sons of obedience', have 'bound ourselves by a bond' to be 'of one condition, one opinion, one hand ... to set up the good (sālih) of the country, remove injustices', and ensure that 'the outsider' should not rule over it. If any ruling emir or tax farmer should commit injustices, they will remonstrate with him, and if necessary 'rise together against him'. The country should pay only 'the original Sultanic tax decreed from olden days'. The notables are enjoined to 'walk according to the ancient customs of [their] forefathers'; transgressors

\footnotetext{
${ }^{107}$ Shidyāq, Akhbār al-a yān, 407-8.

${ }^{108}$ Martin (Journal no. 4), 2 April 1821, AE 306CCC/27.

${ }^{109}$ Shihābī, Tārìkh Ahmad Bāshā al-Jazzār, 479.

${ }^{110}$ Havemann, Rurale Bewegungen, 398-9, discussed 109-11. See also oaths to Emir Bashīr during and after the 1840 rebellion: Asad Rustum, Materials for a Corpus of Arabic Documents Relating to the History of Syria under Mehemet Ali Pasha (Beirut: American Press, 1930), 5:112-14 (doc. 537); 5:126-7 (doc. 547); Touma, Paysans et institutions féodales, 1:179, n. 174.

${ }^{111}$ Yazbik, ed., Awrāq Lubnāniyya 2, 540-3; see also Harik, Politics and Change, 221, n. 79; Shihābī, Lubnān, 3:676-7; Shahwān, 'Ḥayāt Mattā Shahwān', 10; 'N Latoofs Relation', 1r, col. d.
} 
and traitors to the pact are threatened with the action of the group 'as one hand', and the 'wrath of God and his prophets'. ${ }^{112}$

A later document which seems to be a renewal of this pact is still more explicit, laying down 'the conditions of just rule': if the ruler unjustly punishes one of their number, the other signatories will oppose this. If he persists, they will compensate the wronged party: 'we undertake to share his loss among all (jumhūr) of us'.

If the ruler pledges to deliver payments to the [Ottoman] state without the agreement of the whole (jumhīr) of the people of the country - emirs, muqaddams, shaykhs and notables of the commoners - other than the Sultanic tax and obligation fixed for us, we will not accept any of this, nor accept him as ruler over us - not even if he claims he will furnish the payment from his [own] property, because this is what our rulers commonly do, and we and the people of our country bear the consequences. ${ }^{113}$

Jumhür here takes on a different sense from the one that it bears in the commoners' pacts, encompassing not the 'body of the commoners' but the established elite, in their traditional order of rank, plus the notables of the commoners. Still, these two documents attempt to formalize a principle of strict watchfulness over the actions of the ruling emir - in financial matters especially - on the part of the elite and some of the common people of the Mountain. Claiming to codify earlier practice, 'our old way and customs', they nonetheless constitute a more formal 'constitutional' agreement than any that appear to have preceded them. Like so many elaborate covenants, they seem to have remained largely a dead letter. A few years after his re-establishment in power, Emir Bashï decisively broke the power of many of the Druze notables in a move towards 'top-down' centralization. More immediately, in autumn 1821, he collected extra taxes - though we should note that he imposed them on the northern districts which had not been party to the Sumqāniyya pact, suggesting that it protected the southern and central districts to some degree.

This short-lived pact represents a formalized 'negotiated' solution to the problem created by a clash of top-down extractive regime and bottom-up commoner revolt. Though conceived wholly in the terms of a local political culture, it nonetheless fits into a larger contemporary pattern: the rash of Euro-Atlantic constitutions on the pattern of French and American revolutionary ones; the 1808 convention between the Ottoman Sultan and provincial notables; charters conceded by even staunchly monarchical regimes at the European Restoration. ${ }^{114}$ Many such agreements, like the Lebanese one, were soon overtaken by events; but they belong to a broader pattern of 'renegotiation', designed to stabilize the political order after revolution, war, or other upheavals - or to forestall such disruptions. These renegotiated solutions, like the Sumqāniyya pact, tended to combine older understandings of politics with revolutionary innovations. ${ }^{115}$ We can suggest that renegotiations, in their various forms, derived from the logic of a clash between the top-down politics of a military-fiscal regime, and the bottom-up politics of the common people. Some would go on to provide new forms of legitimacy for the unprecedented expansion of state power through the nineteenth century.

\section{Confluences and conclusions}

The innovative forms of language and of popular organization created by the 1821 commoner leagues would be blended, over the course of the nineteenth century, with European-derived ideas

\footnotetext{
${ }^{112}$ Havemann, Rurale Bewegungen, 398-9.

${ }^{113 ،}$ Athar tārīkhì' ('A Vestige of History'), al-Manāra 9 (1938): 96-100. Muqaddam was a rank intermediate between emir and shaykh.

${ }^{114}$ See Linda Colley, 'Writing Constitutions and Writing World History', in The Prospect of Global History, ed. James Belich, John Darwin, Margret Frenz, and Chris Wickham (Oxford: Oxford University Press, 2016), 160-77.

${ }^{115}$ Adelman, 'Age of Imperial Revolutions', 339; see also Bayly, Birth of the Modern World, 139-41.
} 
and forms. In 1840, many groups of Lebanese rose up against the oppressive rule of Mehmed Ali's Egyptian state, a more ambitious military-fiscal project than any they had previously known: it sought not only to tax but to disarm and conscript them. In north-central Mount Lebanon, commoners followed the patterns of 1821, forming armed bands and assemblies and concluding a written pact with Druze allies at the church of Anțalyās, meeting place of the first 1821 league. ${ }^{116}$ European powers were coming to play a far larger role in Lebanese politics: the rebels, commoners and others, now sought to treat not only with Emir Bashīr and Ottoman authorities, but with British and French consuls and agents. ${ }^{117}$ In exchanges with these, a novel political language was coming into use, involving terms such as 'liberty' and opposition to Egyptian 'slavery', as well as references to the recent Ottoman decree that heralded the Tanzimat reforms. ${ }^{118}$ More tellingly, commoner rebels employed them in a proclamation addressed to other Lebanese, evoking both the French revolutionary wars and the Greek revolt: 'the Greeks rose up before you, and attained absolute freedom from God'. ${ }^{119}$

Over the succeeding decades, European-influenced modes of political representation on the basis of religious sect intermingled with forms derived from Mount Lebanon's earlier political culture. This blending would influence, among other things, an 1840 pact among the elite, mass meetings and petitioning in the 1840s and 1850s, a peasant rising in 1858, and sectarian Christian armed bands in $1860 .{ }^{120}$ As elsewhere in the Ottoman empire and across the non-European world, the growing influence of European states and greater familiarity with European intellectual culture led over time to the adoption and adaptation of political vocabularies and forms deriving from the Euro-Atlantic age of revolutions. ${ }^{121}$ It was this confluence that allowed later writers to perceive Lebanese commoner movements from 1821 onwards as expressing French revolutionary or nationalist ideas, or to read pacts among the elite as forms of Lebanese democracy or nationalsectarian power-sharing. ${ }^{122}$

Faced with the apparent diffusion of Euro-Atlantic political forms throughout the nineteenthcentury world, one explanation points to the sheer domination of a specifically European-centred capitalist economy and bureaucratic state system, which encouraged political responses understandable in its own terms - undoubtedly a factor in Mount Lebanon from the 1840s. Another suggests that these Euro-Atlantic innovations were more radical and sophisticated than those elsewhere, owing to the greater intensity of the revolutionary processes from which they sprang. But neither of these necessarily tell us how these political forms came to seem plausible to other people. A possible answer has been suggested by Andrew Sartori, to explain the adoption of 'Lockean' concepts by early twentieth-century Bengali peasants. He points not to the inherent qualities or even the British-imperial prestige of these concepts, but to the fact that they described and explained a set of social conditions and practices - capitalism - which Bengali peasants were

\footnotetext{
${ }^{116}$ Havemann, Rurale Bewegungen, 124-81; Rustum, Materials, 5:100.

${ }^{117}$ Carol Hakim, The Origins of the Lebanese National Idea, 1840-1920 (Berkeley: University of California Press, 2013), 37-9.

${ }^{118}$ See British proclamation, in Rustum, Materials, 5:159 (doc. 564); petition to French ambassador, TNA, FO 78/395; 'Petition from sundry Sheiks' and letter from 'the people of Kisrawān', Sir Richard Wood Papers, 2/2/1840s, Middle East Centre Archive, St Antony's College, Oxford. For the Ottoman decree, see Frederick F. Anscombe, 'Islam and the Age of Ottoman Reform', Past \& Present 208, no. 1 (2010): 159-89.

${ }^{119}$ Rustum, Materials, 5:103 (doc. 531).

${ }^{120}$ 'Traduzione della Copia d'una Convenzione... ', Sir Richard Wood Papers, 4/4; Chevallier, La Société du mont Liban, 157-79; Havemann, Rurale Bewegungen, 182-261; Makdisi, Culture of Sectarianism.

${ }^{121}$ For 'confluences' around the Mediterranean, see Joanna Innes, 'Popular Consent and the European Order', in The Mediterranean in the Age of Revolutions, ed. Innes and Philp, 271-99; Maurizio Isabella and Konstantina Zanou, eds., Mediterranean Diasporas: Politics and Ideas in the Long Nineteenth Century (London: Bloomsbury, 2016). More broadly, see Bayly, Birth of the Modern World, 118-19, 205-18, 302-6; Colley, 'Writing Constitutions'.

${ }^{122}$ Khalifé, 'Les révoltes sociales'; Albert Hourani, Arabic Thought in the Liberal Age, 1798-1939 (London: Oxford University Press, 1962), 61-2; Philip al-Samrānī, 'Da'ā'im al-wațaniyya' ('The Pillars of Nationhood'), al-Manāra 15 (1944): 3-12.
} 
then confronting. Without necessarily knowing much of the original context of English liberal or Lockean ideas, Bengalis found them plausible within their own context. ${ }^{123}$

A similar suggestion could be made for the spread of Euro-Atlantic political innovations of the 'age of revolutions' into other regions. These areas, too, were participating in the shared dynamics outlined above: military competition, the top-down centralization of extractive states, bottom-up organization by the common people, and renegotiated elite responses. Particular Euro-Atlantic political forms, developed in response to these conditions, then appeared plausible to people confronting similar conditions outside the Euro-Atlantic zone. Yet the instance of Mount Lebanon calls our attention to a further possibility. Here, the shared conditions of military-fiscal competition led a distinctive local political culture to create its own response - a bottom-up movement and a renegotiated pact - analogous to Euro-Atlantic and other responses. Later in the nineteenth century, a 'diffusionist' dynamic began, as Lebanese adopted European-derived notions and forms of representation, nationality, and religious community. But this happened in a context not only of material conditions which were converging with those of the Euro-Atlantic zone, but also of locally produced ideas and practices which were themselves innovative responses to the new, shared conditions of commercialization and military-fiscalism. This possibility, as well as that suggested by Sartori, is worth considering in other cases where Euro-Atlantic ideas and political forms seem to have been 'diffused'. Where a European-derived element is present (as in Mount Lebanon from 1840), historians may be tempted to see this as the source of all political innovation, rather than asking whether it is blended with an independent, parallel response to novel conditions. This is the heuristic usefulness of the 1821 case: it makes clear that such a response was possible in the absence of ideological diffusion.

This study of the instance of Mount Lebanon in 1821 has helped to outline a possible framework for the study of the age of revolutions. This framework involves accepting, in large part, recent historians' geographical extension of the age of revolutions beyond the Euro-Atlantic zone; but it explains the parallel revolutionary patterns across this extended area - including within the Euro-Atlantic zone itself - in terms less of intellectual circulations than of shared politicoeconomic dynamics. Distinct political cultures might respond largely in their own terms to the common challenge of rising military-fiscal competition, with its tendency to pit top-down regimes against bottom-up political organization; or they might blend local forms with those borrowed from other cultures experiencing similar processes. In either case, many of the parallelisms between 'revolutionary' processes noted by scholars may be traced less to ideological circulation than to logics deriving from the shared process of military-fiscal escalation. This put three factors - 'frontier' lands, money or monetizable wealth, and military or otherwise mobilizable personnel at a premium, while stripping away the negotiated forms which had interposed themselves between the military-fiscal extraction of wealth and its producers. This combination could, in certain circumstances, allow the emergence of bottom-up forms of politics in which 'commoners' organized for their own ends; and this, or the threat of it, could lead to the renegotiation of the political order. These parallel processes of politico-cultural innovation, along with the shared material conditions which underpinned them, then paved the way for the later appropriation of political innovations from the Euro-Atlantic zone which had experienced the 'age of revolutions' in its most intense form.

There remain unanswered questions, two of which seem especially important. First, how far can such a model extend geographically, and does it apply only very unevenly to different areas? Notions of unevenness might help us explain both the evident differences in outcome of revolutionary episodes themselves, and the contrasting trajectories of the relevant societies in the postrevolutionary period. Some peoples and regions, of course, must be seen as falling outside the model: but, rather than simply pointing to them as counter-examples, we should enquire why their political dynamics were different. Second, how unique were such processes to this this

${ }^{123}$ Andrew Sartori, Liberalism in Empire: An Alternative History (Oakland: University of California Press, 2014), chap. 1. 
particular 'age'? Many have argued that the age of revolutions needs to be seen in relation to earlier cycles, especially the 'crisis of the seventeenth century'. Drawing such connections raises the question of ulterior causes lying behind the dynamics of military-fiscalism - to be found, it has been variously argued, in demographic trends, climactic events, or cycles of capitalist accumulation. ${ }^{124}$ It is in the direction of addressing such questions, and of testing shared frameworks and logics such as that proposed above, that I suggest the 'global age of revolutions' debate should now move.

Peter Hill is a historian of the modern Middle East, specializing in the Arab world during the long nineteenth century. His research focuses on political thought and practice, the politics of religion, and translation and intercultural exchanges. He also has a strong interest in comparative and global history. His first book, Utopia and Civilisation in the Arab Nahda, was published by Cambridge University Press in 2020. He has also published articles in journals including Past \& Present, the Journal of Arabic Literature, and Intellectual History Review.

\footnotetext{
${ }^{124}$ See, respectively, Jack A. Goldstone, Revolution and Rebellion in the Early Modern World (Berkeley: University of California Press, 1991); Geoffrey Parker, Global Crisis: War, Climate Change and Catastrophe in the Seventeenth Century (New Haven: Yale University Press, 2013); and Giovanni Arrighi, The Long Twentieth Century: Money, Power, and the Origins of Our Times (London: Verso, 1994).
}

Cite this article: Hill P. 2021. How global was the age of revolutions? The case of Mount Lebanon, 1821. Journal of Global History 16: 65-84, doi:10.1017/S1740022820000145 